\title{
Article
}

\section{Research on the Impact of Online Promotions on Consumers' Impulsive Online Shopping Intentions}

\author{
Hanyang Luo ${ }^{1}$, Sijia Cheng ${ }^{2}$, Wanhua Zhou ${ }^{2}$, Wugang Song ${ }^{2}$, Sumin $\mathrm{Yu}^{1, *}$ and Xudong Lin ${ }^{1}$ \\ 1 Institute of Big Data Intelligent Management and Decision, College of Management, Shenzhen University, \\ Shenzhen 518060, China; hanyang@szu.edu.cn (H.L.); xudonlin@szu.edu.cn (X.L.) \\ 2 College of Management, Shenzhen University, Shenzhen 518060, China; 1900132009@email.szu.edu.cn (S.C.); \\ 2060132016@email.szu.edu.cn (W.Z.); 2100132004@email.szu.edu.cn (W.S.) \\ * Correspondence: yusumin@szu.edu.cn
}

Citation: Luo, H.; Cheng, S.; Zhou, W.; Song, W.; Yu, S.; Lin, X. Research on the Impact of Online Promotions on Consumers' Impulsive Online Shopping Intentions. J. Theor. Appl. Electron. Commer. Res. 2021, 16, 2386-2404. https://doi.org/10.3390/ jtaer16060131

Academic Editor: José Ramón Saura

Received: 25 July 2021

Accepted: 6 September 2021

Published: 14 September 2021

Publisher's Note: MDPI stays neutral with regard to jurisdictional claims in published maps and institutional affiliations.

Copyright: (c) 2021 by the authors. Licensee MDPI, Basel, Switzerland. This article is an open access article distributed under the terms and conditions of the Creative Commons Attribution (CC BY) license (https:// creativecommons.org/licenses/by/ $4.0 /)$.

\begin{abstract}
Online shopping has developed rapidly, but recently, the sales of some online stores have suffered due to the decrease in people's income caused by the epidemic. How to grasp the psychology and behavior of consumers and formulate effective marketing strategies is important for increasing sales. This paper puts forward a research model and eight hypotheses based on the research on the promotion situation and the types of products promoted on consumers' impulse shopping, and uses regression analysis, $t$-test, stepwise regression and analysis of variance to conduct data analysis. The results show that online promotion has a significant impact on consumers' willingness, and the anticipated regrets in different directions have totally different effect on willingness; the type of product promoted, and the impulsive characteristics of consumers play a moderating role; online promotion affects consumers' impulsive online shopping intentions through the intermediary effect of expected regret. The influence of anticipated regrets on impulsive online shopping intention is proposed creatively, and the results also provide e-commerce merchants and customers with new insights in managing and treating online promotions. Managerial implications like controlling the duration of promotions and the number of preferential goods are put forward based on our analysis.
\end{abstract}

Keywords: online promotion; anticipated regret theory; impulsive traits; impulsive online buying intention; fast-moving consumer goods

\section{Introduction}

Since the spread of COVID-19, the epidemic has brought untold hardship to the whole world. However, lockdowns are also driving a move to the online shopping industry. The negative impact of the epidemic on residents' income has led to the decline of consumption ability and a slight increase in their sensitivity to promotional activities. Exploration on consumer psychology and marketing strategies attracts attention from various online businesses. To maximize the benefits of sales, it is important for retailers to understand impulse buying mechanism and come up with sound promotion guidelines.

To compete with each other, online retailers often offer significant discounts with limited quantities and time in an attempt to push impulse buying intention. Compared with planned online shopping, impulsive online shopping has higher randomness and suddenness. According to the "Chinese Consumers Online Consumption Insight Report and Online Shopping Guide (2016)" [1], 53.1\% of respondents have stockpiled for online promotions, and $65.1 \%$ said that they return goods frequently after online shopping. Such evidence suggests that impulse shopping is in a common sight in the internet world. As a kind of consumer behavior, it has certain research value, and therefore, it has become an important branch of related fields. Online promotions are often run in various conditions (such as flash sales that sell at a favorable price with a time limit) to give consumers a sense of urgency to purchase the products. Therefore, consumers themselves should also 
understand the generation principles of impulsive purchase intentions and manage their own online shopping desires to avoid shoppers' remorse.

Scholars like Greenfield found that impulsive buying behavior exists in online shopping [2]. However, few studies introduce consumers' anticipated regret in online shopping, and related research tend to investigate the influence of downward expected regret on impulsive purchase intentions. While the impact of upward anticipated regret on impulsive purchase intensions is less explored. Therefore, this paper complements the innovative downward anticipation research, explores these two types of anticipated regrets and studies the impact of this scenario on consumers' impulse purchase intentions. By analyzing the internal reaction mechanism of online promotion that affects consumers' impulse shopping, it can help online businesses formulate effective marketing strategies to attract consumers.

Based on the characteristics of the types of online promotion, this paper introduces the variable of consumer's anticipated regret and the stimulus-organism-reaction (SOR) model to study the impact of online promotions on consumers' impulsive purchase intention. Our research provides companies with a new insight in achieving sales goals, and at the same time, allows consumers to rationally view online promotions and provide suggestions to avoid excessive impulsive consumption. To a certain extent, our research can enrich the content of related research on impulsive online shopping intention.

\section{Literature Review}

\subsection{Stimulus-Organism-Reaction Model}

The stimulus-organism-reaction (SOR) model (illustrated in Figure 1) based on environmental psychology was proposed by Woodworth in 1929 [3], and subsequently expanded to other fields. In the study of marketing, external stimulus (S) lead to consumers' emotional reactions $(\mathrm{O})$, which in turn drive their behavioral responses $(\mathrm{R})[4,5]$. Using the SOR model, many scholars have attached importance to the influence of environmental stimulus on emotion and successfully used the stimulus as predictor to predict consumer behaviors. The SOR model is extensively used in marketing strategy development research. For example, Liu believed that the food safety incidents and environment orientation can attract consumers' hyper attention and significantly affect consumers' response to purchase organic food [6]. In the previous studies on consumer impulse buying behavior, most of the studies are based on SOR theory, using least squares, regression analysis, structural equation and other methods for further problem research [7-9]. SOR theory can better reflect consumers' emotional changes and behavioral processes. Therefore, this paper also adopts SOR model as our theoretical framework, using regression analysis, $t$-tests and other methods to investigate the relationship between consumer anticipated regret, promotion methods and consumer impulse purchase intention.

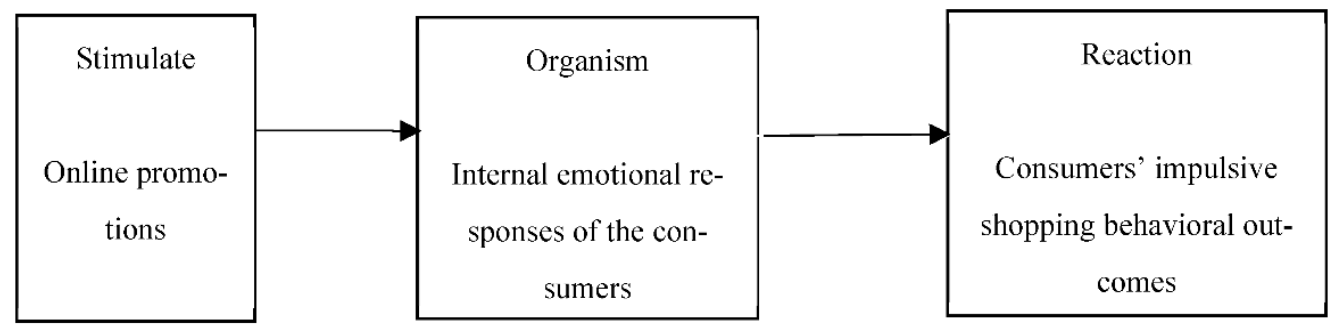

Figure 1. S-O-R model.

In this paper, stimulus represents promotion methods such as time-limited promotion and quantity-limited promotion. The organism here represents the inner emotion and psychological process of consumers after experiencing the stimulus, that is, the expectation of regret. Response in the model refers to the individual's final behavioral results, which may be positive or negative $[10,11]$. The impulsive shopping behaviors in this study represent behavioral outcomes and changes that have occurred among customers as a reaction to the online sales promotions. 


\subsection{Promotion Types}

Promotion is usually considered an important marketing technique in attracting customers. Consumers might not give it much thought when receiving benefits, but retailers are keen to see their reaction and ultimately make them buy more.

One of the most important and common marketing models is the $4 \mathrm{P}$ theory mentioned in "Basic Marketing" published by American marketing scientist Jerome McCarthy in 1960, namely product, price, place, promotion [12]. Since then, the word "promotion" has become widely known.

Retailers can make use of advanced software and communication tools to convey promotion information to consumers in more various forms, and interact with consumers to get feedback. Limited promotion is the most common way of promotion because the scarcity of preferential products increases consumers' perceived value of products and gives them a sense of urgency, thus leading to impulsive buying [13]. In practice, quantity-limited and time-limited promotions are widely used. Compared with the other means, offering favorable prices in a short time slot brings time pressure on consumers because they need to make purchase decision in a shorter time, which will arouse their sense of urgency to some extent, thus improving the transaction speed [14-17]. In the quantity-limited promotion, only a certain number of consumers can buy products at a discounted price or receive gifts. Rarity is the tactic employed by e-commerce practitioners who make consumers think that they are competing with each other for limited number of products. Some scholars have shown that, due to limited production quantity, consumers would feel the value or uniqueness of the products and have a greater urgency to purchase them [18-20].

\subsection{Anticipated Regret}

Regret typically occurs when an individual assumes that another decision will yield better results after he or she has taken an action. According to the order of actual decisionmaking and emotional change, it can be divided into anticipated regret and experienced regret [21]. This paper mainly discusses the former one. Anticipated regret refers to the anxiety caused by the fear of possible loss before making a decision. It would result in hesitation when making purchase decisions [22]. If consumers feel that they will regret the decision to buy or not, they will evaluate their decisions more carefully [23,24]. The study of Zeelenberg et al. also confirmed that anticipated regret would prompt samples to choose a safer option, namely risk aversion [25]. However, Larrick and Boles found that anticipated regret can make people pursue risks rather than avoid them [26]. Ritov's study also confirmed that when subjects were placed in a gambling choice situation, people would engage in risk-seeking behavior due to the increased tendency of anticipated regret [27]. When starting from the perspective of downward counterfactual thinking, people tend to compare the result of a decision with the result of a worse plan. This idea is called downward anticipated regret, also known as inaction regret. When consumers have upward expectations of regret, they will perceive that their own benefits decrease with the actions they take, thereby reducing the possibility of action and inhibiting the occurrence of actions; when consumers have downward expectations regrets, they will perceive that their own benefits will follow paying for action increases, and not paying for action will result in a decrease in revenue, thereby increasing the possibility of the action.

Few studies have divided anticipated regret into upward regret and downward regret, and most scholars treat them as identical variables without distinction. In fact, the upward anticipated regret commonly inhibits the individual's desire to act, while the downward anticipated regret stimulates the individual's desire to act. The difference between the two is very obvious. Therefore, this paper divides expected regret into two dimensions, and more specifically analyzes its relationship with online promotion and consumers' impulsive online shopping intention. 


\subsection{Impulsive Buying}

Impulsive buying is defined as unplanned and sudden purchase behavior, and it is always triggered by the shopping environment. Consumers are motivated by a strong impulse. When this impulse occurs, it is difficult for them to resist buying. This behavior is often accompanied by happiness and passion. However, due to the lack of thoughtful trade-offs, consumers generally feel anxiety and regret after purchase [28-30].

Many scholars have studied from the perspective of consumers and observed that individual factors play an important role in stimulating impulsive purchase, such as low self-control, impulsive personality and the shopping values of vanity and enjoyment [3133]. Earlier research also discussed the stimulating effects of external factors. In 1951, William Applebaum proposed that impulsive behavior is caused by the stimulus created by the store [34]. Wang Yanzhi et al. probed into the internal mechanism of impulsive buying behavior when shopping with others from the perspective of communities [35]. With the development of e-commerce, more researchers have a focus on online impulsive buying behavior. Some of them believed that consumers were surrounded by various sales information and interactions between buyer and seller on social media at any time, resulting in stronger impact of purchase stimulus and impulsive purchase [36,37]. Online promotion has attracted the attention of many businesses because of its diversified and eyecatching forms of product presentation, and has become a necessary means of marketing. This paper aims to the relationship between online promotion and consumers' impulsive online purchase intention.

\section{Models and Hypotheses}

Online promotion has attracted the attention of a wide range of merchants due to its diverse and vivid expressions, making online promotion a necessary marketing method for merchants today. In practice, online promotions will not be applied independently but are used in combination with other means like limiting the period of discounts and the number of goods promoted. The increase in restrictive conditions will cause changes in consumers' expectations and affect their judgment of the current state. A large number of studies show that in promotional activities, restrictive conditions will stimulate consumers' sense of urgency and anxiety, make them feel they are competing with others, and also affect consumers' expected emotional response, thus affecting their impulsive online shopping intention [17-19]. Impulsive traits are inherent characteristics of an individual. Generally speaking, this trait is hard to be changed. It affects individual decision-making behavior, just as human hormones affect body state. The level of impulsive traits is commonly manifested in individual impulsive willingness or differences in behavior [6-8], which has become the focus of research in the field of consumer behavior.

This paper will use the SOR model as the theoretical basis of the research model, with limited time and a limited number of online promotions as independent variables, anticipated regret as an intermediate indicator, and consumers' impulsive online shopping willingness as the outcome variable to determine "online promotion, anticipated regret, impulse online shopping willingness" research model. In addition, whether the promoted product is a fast-moving consumer product is used as the moderating variable of the anticipated regret of online promotion, and the impulsive trait is used as the moderating variable of the anticipated regret of impulsive online shopping intention to investigate its influence mechanism. The model is shown in Figure 2. 


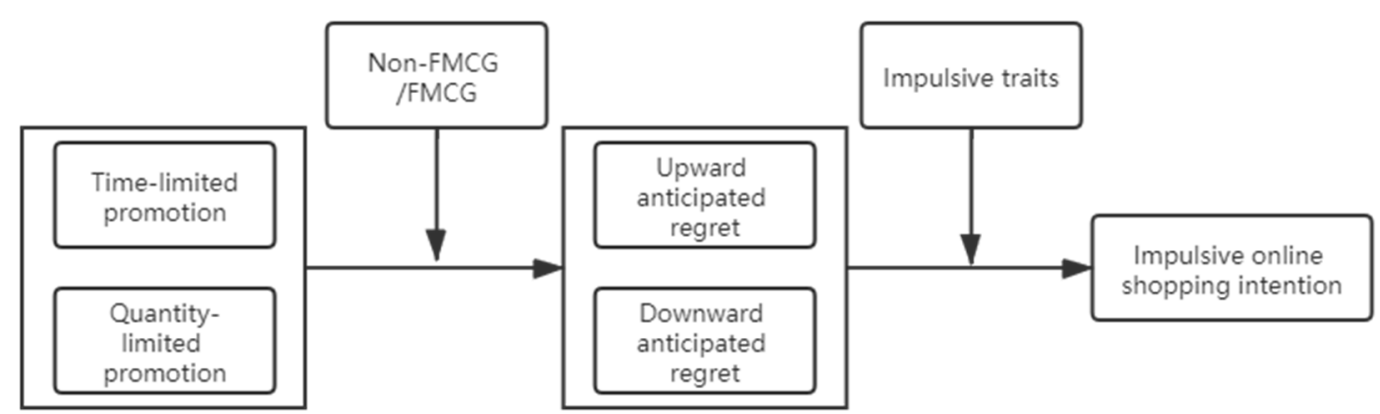

Figure 2. Research model.

When faced with time-limited or quantity-limited online promotion consumers can learn the remaining time for the promotion and the remaining quantity of the promoted goods. The passage of time and the reduction of quantity are signals that bring pressure to consumers, making consumers weigh whether to buy urgently. In time-limited promotions, consumers are faced with the pressure of time, while in quantity-limited promotions, although consumers do not face time constraints, they need to compete with other consumers, so they will face a stronger sense of urgency. Based on the above statement, we propose the following hypotheses:

Hypothesis 1 (H1). Compared with the upward anticipated regret, time-limited promotions have a more significant impact on the downward anticipated regret.

Hypothesis 2 (H2). Compared with the upward anticipated regret, the quantity-limited promotions have a more significant impact on the downward anticipated regret.

Hypothesis 3 (H3). Compared with time-limited promotions, quantity-limited promotions can stimulate downward anticipated regret.

FMCG is characterized by a short consumption cycle, fast consumption speed and frequent use non-fast-moving consumer goods refer to the products that have a long consumption cycle and slow consumption speed, and can also be called durable goods. Compared with non-FMCG, FMCG has a higher degree of homogeneity, and consumers' requirements or loyalty to their brand will be relatively weakened. The main feature of selling fast-moving consumer goods through online channels is that they are regularly promoted $[38,39]$. It can be seen that online promotion of fast-moving consumer goods can stimulate consumers' regret, thereby enhancing consumers' willingness to purchase. However, on the other hand, the profit of FMCG is meager, and the increase in its profit is normally achieved by holding frequent promotional activities. Therefore, consumers may have doubts about whether it will be more beneficial next time and the possibility of impulsive online shopping will decline. Based on the above statement, we propose the following hypotheses:

Hypothesis 4 (H4). Compared with non-FMCG, the online promotion of FMCG has a more significant impact on consumers' anticipated regret.

Hypothesis $4 \mathbf{a}$ (H4a). In time-limited promotions, consumers have stronger upward anticipated regret and downward anticipated regret for the online promotion of FMCG.

Hypothesis $\mathbf{4 b} \mathbf{( H 4 b ) . ~ I n ~ q u a n t i t y - l i m i t e d ~ p r o m o t i o n s , ~ c o n s u m e r s ~ h a v e ~ s t r o n g e r ~ u p w a r d ~ a n d ~}$ downward anticipated regrets for online promotion of FMCG.

People dislike the feeling of regret after the event due to poor decision-making leading to loss of profits. This also allows consumers to anticipate possible outcomes before making 
a purchase decision and choose the decision that minimizes the degree of regret. Yin Chengyue points out in his research that consumer anticipated regret can be classified into upward anticipated regret and downward anticipated regret according to the dimensions of counterfactual thinking. Among them, upward anticipated regret is also referred to as the action effect in the psychology of regret, and downward anticipated regret is also referred to as the inaction effect in the psychology of regret [40]. If consumers think they can buy at a lower price in the future, they will feel that the present is not the best time to buy and reduce impulsive buying; if consumers think there will be no such discount after promotion, they will think this is the best time to buy. Based on the above statement, we propose the following hypotheses:

Hypothesis 5 (H5). The upward anticipated regret will negatively affect consumers' impulsive online shopping willingness.

Hypothesis 6 (H6). The downward anticipated regret will positively affect consumers' impulsive online shopping willingness.

Consumers weigh their purchase decisions to reduce the possibility of regret, so they often show impulsive online shopping intentions in different directions. If they buy it now, they will regret when they encounter a greater discount in the future; if they do not buy it now, there will be no such benefits in the future, and they will also regret it. Both of these possibilities will affect consumers' purchase intention. Based on the above statements, this study hypothesizes:

Hypothesis 7 (H7). In the relationship between online promotion and consumers' impulsive online shopping willingness, consumers anticipated regret plays an intermediary role.

Individual impulsive traits belong to the internal characteristics of consumers. The level of the traits can measure consumers' impulsivity in purchase decision-making. Impulsivity can lead to excessive buying and even pathological buying [41-43]. Consumers with high impulsivity commonly buy more when faced with online promotion stimuli. Descending counterfactual thinking will generate downward anticipated regret, which will stimulate impulsive online shopping intentions. Consumers with less impulsivity tend to think carefully before making a purchase, reducing their impulsivity before making decisions. Therefore, we hypothesize:

Hypothesis 8 (H8). In the influence of consumers' anticipated regret on impulsive online shopping willingness, impulsive traits have a significant moderating effect.

\section{Materials and Methods}

This paper studies the impact of online promotions on consumers' impulsive purchase intention and the influence of anticipated regret from the two perspectives of time-limited promotion and quantity-limited promotion, and commodity attributes and consumer impulsive characteristics are set as the moderating variables. In order to ensure the reliability of the results, some successful experiences in earlier research are used for reference when selecting the measurement indicators of the relevant variables. In addition, the indicators are tested and adjusted according to the actual situation in advance.

The questionnaire is divided into four parts according to the type of promotion and whether the promoted product is a fast-moving consumer product: fast-movinglimited time, fast-moving-limited quantity, non-fast-moving-limited time, and non-fastmoving-limited quantity. In addition, some specific promotion scenes are described in the questionnaire, which aims to bring respondents into a more realistic online purchase situation and improve the authenticity of answers. Several possible scenarios are as follows:

Scenario descriptions of the fast-moving-limited-time promotion: You plan to buy one fashionable dress on the e-commerce platform. In the process of browsing the products, 
you see a snack bag. The brand of the snack bag is your favorite. The taste, packaging, weight and customer reviews all meet your requirements. You like this snack bag very much, and you have enough money to buy it at the original price. Further, this product will be promoted for three days at a $20 \%$ discount from today.

Scenario descriptions of the non-fast-moving-limited-time promotion: You plan to buy one fashionable dress on the e-commerce platform. In the process of browsing the products, you see a pair of sneakers The brand of the sneakers is your favorite. Its design style, comfort, functionality and customer reviews all meet your requirements. You like it very much, and you have enough money to buy it at the original price. Further, this product will be promoted for three days at a $20 \%$ discount from today.

In the limited quantity promotion scenes, the specific promotion is replaced with "You can buy it at a $20 \%$ discount if you are one of the first 100 consumers".

Table 1 shows the measurement items of the four variables: upward anticipated regret, downward anticipated regret, personal impulsive traits, and impulsive online purchase willingness.

Table 1. Research variable measurement items.

\begin{tabular}{|c|c|c|c|}
\hline Research Variables & $\begin{array}{l}\text { Measurement } \\
\text { Indicators }\end{array}$ & Measurement Items & Reference Scale \\
\hline \multirow{3}{*}{$\begin{array}{l}\text { Upward anticipated } \\
\text { regret }\end{array}$} & SHH1 & $\begin{array}{l}\text { Buy it now. If the discount on this product is larger in } \\
\text { the future, I will regret it. }\end{array}$ & \multirow{7}{*}{ Hetts (2000) [44] } \\
\hline & SHH2 & $\begin{array}{l}\text { Buy it now. If I find that it will be cheaper in other } \\
\text { stores in the future, I will regret it. }\end{array}$ & \\
\hline & SHH3 & $\begin{array}{l}\text { Buy it now. Considering that buying will cost more } \\
\text { than not buying, I will regret it. }\end{array}$ & \\
\hline \multirow{4}{*}{$\begin{array}{l}\text { Downward } \\
\text { anticipated regret }\end{array}$} & XHH1 & $\begin{array}{l}\text { After the product is sold out, it may become out of } \\
\text { production. I will regret it if I do not buy it now. } \\
\text { In the future, I will find that the product will be }\end{array}$ & \\
\hline & XHH2 & restored to its original price. If I do not buy it now, I & \\
\hline & & will regret it. & \\
\hline & ХHH3 & $\begin{array}{l}\text { I will find that this product is more costly in other } \\
\text { stores in the future. I will regret it if I do not buy it } \\
\text { now. }\end{array}$ & \\
\hline \multirow{5}{*}{$\begin{array}{l}\text { Personal impulsive } \\
\text { traits }\end{array}$} & TZ1 & I do not need to think about it too carefully. & \multirow{5}{*}{$\begin{array}{l}\text { Rook and Fisher (1995) } \\
\text { [45] }\end{array}$} \\
\hline & $\mathrm{TZ2}$ & I regularly act on a whim. & \\
\hline & TZ3 & I can make a decision soon. & \\
\hline & $\mathrm{TZ4}$ & $\begin{array}{c}\text { I get bored easily when solving problems that require } \\
\text { thinking. }\end{array}$ & \\
\hline & TZ5 & My self-control ability is weak. & \\
\hline \multirow{3}{*}{$\begin{array}{l}\text { Impulsive online } \\
\text { purchase intention }\end{array}$} & YY1 & $\begin{array}{l}\text { When shopping online, I have a strong desire to buy } \\
\text { products that I do not plan but like. }\end{array}$ & \multirow{3}{*}{$\begin{array}{l}\text { Jones, Weun and Beatty } \\
\text { (2003) [46] }\end{array}$} \\
\hline & YY2 & $\begin{array}{l}\text { When shopping online, I often find that there are } \\
\text { things I want to buy outside of my shopping plan. }\end{array}$ & \\
\hline & YY3 & $\begin{array}{l}\text { Seeing this promotional item, I will involuntarily want } \\
\text { to buy it even though it is not in my shopping plan. }\end{array}$ & \\
\hline
\end{tabular}

After pre-investigation and questionnaire revision, the final questionnaire was released and collected on Wenjuanxing, China's largest questionnaire platform which is open to all the Chinese netizens. After explaining the purpose of the survey and expressing gratitude, participants were asked to answer in the corresponding shopping scene. A total of 430 questionnaires were collected, excluding invalid questionnaires with short answering time and incomplete questionnaires, and 415 were valid, with a recovery efficiency of $96.5 \%$. Among the valid questionnaires, 99 copies were collected for FMCG-limited time scenes, 114 copies were collected for FMCG-limited quantity scenes, 101 copies were collected for non-FMCG-limited time scenes, and 101 copies were collected for non-FMCG-limited 
quantity scenes. All valid questionnaire data were collected and analyzed by SPSS24.0, a sociology statistical software for data analysis, to verify the proposed hypothesis and to reach the research conclusion.

As shown in Table A1 in the Appendix A, the ratio of male respondents to female respondents was nearly close to $1: 1$; in terms of the age, $92.5 \%$ of the respondents are between 18 and 30 years old, which is essentially in line with online shoppers. From the perspective of educational background, $85.1 \%$ of the respondents are mainly at the level of undergraduate and below. As for the average monthly consumption of online purchase, most of the respondents' monthly expenditure on online purchase is within CNY 1500 , accounting for $89.6 \%$. A total of $46 \%$ of the respondents spend an average of 500 to $1000 \mathrm{CNY}$ on online shopping per month. It can be seen from the descriptive statistical characteristics that the surveyed samples have rich online shopping experience and meet the needs of this research. Then we analyze the reliability and validity of the data.

In order to test Hypotheses H1 (compared with upward anticipated regret, timelimited promotion has a more significant impact on downward anticipated regret) and $\mathrm{H} 2$ (compared with upward anticipated regret, limited quantity promotion has a more significant impact on downward anticipated regret) and H3 (compared with time-limited promotions, quantity-limited promotions can stimulate downward expectation of regret), the paired-sample $t$-test is used for verification.

In order to test Hypothesis H4 (compared with non-FMCG, online promotion of FMCG has a more significant impact on consumers' anticipated regret), this paper adopts the independent sample $t$-test after dividing the data into two types: time-limited promotion and quantity-limited promotion.

This paper uses the regression analysis to test $\mathrm{H} 5$ (upward anticipated regret will negatively affect consumers' impulsive online purchase intention), H6 (downward anticipated regret will positively affect consumers' impulsive purchase shopping intention), H7 (in the relationship between online promotion and consumers' impulsive online purchase willingness, consumers anticipated regret plays an intermediary role) and H8 (in the influence of consumers' anticipated regret on impulsive online purchase willingness, impulsive characteristics have a significant moderating effect).

In this paper, the online promotion, anticipated regret and consumers' impulsive online purchase willingness are set as the independent variable, the intermediary variable and the dependent variable, respectively. The stepwise method is applied to test the intermediary effect of consumers' anticipated regret.

As shown in Equations (1)-(3), $\mathrm{Y}$ is the outcome variable, $\mathrm{X}$ is the independent variable, and $\mathrm{M}$ is the intermediary variable. In the stepwise method, the corresponding coefficients $a, b, c$ and $c^{\prime}$ should be subject to significance tests.

$$
\begin{gathered}
\mathrm{Y}=\mathrm{c} X+\mathrm{e}_{1} \\
\mathrm{M}=\mathrm{aX}+\mathrm{e}_{2} \\
\mathrm{Y}=\mathrm{c}^{\prime} \mathrm{X}+\mathrm{bM}+\mathrm{e}_{3}
\end{gathered}
$$

\section{Results}

\subsection{Reliability Analysis}

The reliability analysis results of this research are shown in Table 2. The $\alpha$ coefficient of each variable is greater than 0.7 , and the $\alpha$ coefficient of all variables is also greater than 0.7 , indicating that the inherent reliability of the questionnaire is at an acceptable level. 
Table 2. Reliability analysis results.

\begin{tabular}{ccc}
\hline Variable & Number of Items & Cronbach Alpha Coefficient \\
\hline Upward anticipated regret & 3 & 0.706 \\
Downward anticipated regret & 3 & 0.772 \\
Impulsive traits & 5 & 0.865 \\
Impulsive online shopping intention & 3 & 0.718 \\
All variables & 14 & 0.832 \\
\hline
\end{tabular}

\subsection{Validity Analysis}

The results in Table 3 show that the KMO value is $0.851, p<0.001$, indicating that the data are highly suitable for factor analysis.

Table 3. KMO value and Bartlett's sphericity test.

\begin{tabular}{ccc}
\hline \multicolumn{3}{c}{ KMO Value and Bartlett's Sphericity Test } \\
\hline KMO sampling appropriateness number & 0.851 \\
& Approximate Chi-square & 2263.591 \\
Bartlett sphericity test & Degree of freedom & 91 \\
& Significance & 0.000 \\
\hline
\end{tabular}

Four factors are extracted by principal component analysis. As shown in Table 4 , the cumulative variance contribution rate of these four factors is $66.293 \%$, which is greater than $60 \%$, indicating that the extracted factors can explain most of the samples' information. The results of exploratory factor analysis are shown in Table 5. Each index can be well attributable to the corresponding variable, and the load value of each index on the attributable factor is greater than 0.5 , indicating that there is a good difference between all variables' validity.

Table 4. Variance interpretation results.

\begin{tabular}{cccc}
\hline Factor Component & Eigenvalues & $\begin{array}{c}\text { Variance Explained } \\
\text { Rate }\end{array}$ & $\begin{array}{c}\text { Cumulative Variance } \\
\text { Contribution Rate }\end{array}$ \\
\hline 1 & 3.625 & $25.891 \%$ & $25.891 \%$ \\
2 & 2.243 & $16.021 \%$ & $41.911 \%$ \\
3 & 1.800 & $12.855 \%$ & $54.766 \%$ \\
4 & 1.614 & $11.526 \%$ & $66.293 \%$ \\
\hline
\end{tabular}

Table 5. Results of exploratory factor analysis.

\begin{tabular}{lcccc}
\hline & \multicolumn{4}{c}{ Rotated Component Matrix } \\
& \multicolumn{4}{c}{ Component } \\
\cline { 2 - 5 } & $\mathbf{1}$ & $\mathbf{2}$ & $\mathbf{3}$ & \\
\hline SHH1 & & & 0.799 \\
SHH2 & & & 0.822 \\
SHH3 & & 0.760 & 0.522 \\
XHH1 & & 0.794 & \\
XHH2 & & 0.797 & \\
XHH3 & & & \\
TZ1 & 0.821 & & \\
TZ2 & 0.761 & & \\
TZ3 & 0.773 & & \\
\hline
\end{tabular}


Table 5. Cont.

\begin{tabular}{lcccc}
\hline & \multicolumn{3}{c}{ Rotated Component Matrix } \\
& \multicolumn{3}{c}{ Component } \\
\cline { 2 - 4 } & $\mathbf{1}$ & $\mathbf{2}$ & $\mathbf{3}$ \\
\hline TZ4 & 0.780 & & \\
TZ5 & 0.767 & & \\
YY1 & & & 0.632 \\
YY2 & & & 0.737 \\
YY3 & & & 0.543
\end{tabular}

Extraction method: principal component analysis method. Rotation method: Caesar normalized maximum variance method. The rotation has converged after six iterations.

\subsection{Hypothetical Test}

In the test of $\mathrm{H} 1$ and $\mathrm{H} 2$, it can be seen from the analysis results in Table 6 that in the time-limited promotions, the average upward anticipated satisfaction is 3.3967, which is smaller than the average downward anticipated regret (3.8200), and the significance level $p=0.000(<0.05)$, indicating that the time-limited promotions have an effect on consumers anticipated regret. The impact on downward anticipated regret is more significant than that on upward expectation regret. Hypothesis H1 is proved.

Table 6. The impact of time-limited promotions on anticipated regret.

\begin{tabular}{ccccccc}
\hline Variable & Average & $\begin{array}{c}\text { Standard } \\
\text { Deviation }\end{array}$ & Correlation & $\mathbf{t}$ & $\begin{array}{c}\text { Degree of } \\
\text { Freedom }\end{array}$ & $\begin{array}{c}\text { Significance } \\
\text { (Two-Tailed) }\end{array}$ \\
\hline $\begin{array}{c}\text { upward anticipated regret } \\
\text { downward anticipated regret }\end{array}$ & 3.3967 & 0.43235 & $0.554(p=0.000)$ & -14.691 & 199 & 0.000 \\
\hline
\end{tabular}

It can be seen from the analysis results in Table 7 that in the quantity-limited promotions, the average upward anticipated regret is 3.7798 , which is less than the average downward anticipated regret (4.2450), and the significance level is $p=0.000(<0.05)$, indicating that quantity-limited promotions have an impact on consumers. The impact on downward anticipated regret is more significant than that on upward anticipated regret. Hypothesis $\mathrm{H} 2$ is proved.

Table 7. The impact of quantity-limited promotions on anticipated regret.

\begin{tabular}{ccccccc}
\hline Variable & Average & $\begin{array}{c}\text { Standard } \\
\text { Deviation }\end{array}$ & Correlation & $\mathbf{t}$ & $\begin{array}{c}\text { Degree of } \\
\text { Freedom }\end{array}$ & $\begin{array}{c}\text { Significance } \\
\text { (Two-Tailed) }\end{array}$ \\
\hline upward anticipated regret & 3.7798 & 0.56103 & $0.396(p=0.000)$ & -11.052 & 214 & 0.000 \\
downward anticipated regret & 4.2450 & 0.56180 & & & \\
\hline
\end{tabular}

Test results of H3 (compared with time-limited promotions, quantity-limited promotions can stimulate downward expectation of regret) are shown in Table 8. The mean value of the time-limited promotions group is 3.8200, and the mean value of the time-limited promotions group is $4.2450, \mathrm{t}=-8.685, p=0.000(<0.05)$, which means that compared with time-limited promotions, quantity-limited promotions have a more significant impact on downward anticipated regret. Thus, $\mathrm{H} 3$ is proven. The greatest difference between quantity-limited promotions and time-limited promotions is that in quantity-limited promotions, consumers need to compete with others for the limited number of marketing items, and consumers will perceive stronger uncertainty. 
Table 8. The impact of time-limited and time-limited promotions on downward anticipated regret.

\begin{tabular}{|c|c|c|c|c|c|c|}
\hline Group & $\begin{array}{c}\text { Number of } \\
\text { Samples }\end{array}$ & $\begin{array}{l}\text { Standard } \\
\text { Deviation }\end{array}$ & Correlation & $\mathbf{t}$ & $\begin{array}{l}\text { Degree of } \\
\text { Freedom }\end{array}$ & $\begin{array}{l}\text { Significance } \\
\text { (Two-Tailed) }\end{array}$ \\
\hline time-limited promotions & 200 & 3.8200 & 0.43034 & \multirow{2}{*}{-8.685} & \multirow{2}{*}{398.577} & \multirow{2}{*}{0.000} \\
\hline quantity-limited promotions & 215 & 4.2450 & 0.56180 & & & \\
\hline
\end{tabular}

The test results of $\mathrm{H} 1$ and $\mathrm{H} 2$ prove that the two different promotion methods have a more significant impact on downward anticipated regret, which is consistent with the conclusion of previous studies, that is, upward anticipated regret inhibits the individual's desire to act, while downward anticipated regret is more likely to stimulate purchasing behaviors. The test results of $\mathrm{H} 3$ also confirmed the previous research on limited time and limited quantity promotions. The quantity restriction will send a stronger signal of scarcity to consumers, keep consumers in a competitive state, and stimulate consumers' desire to buy.

In the test of $\mathrm{H} 4$, the test results of $\mathrm{H} 4 \mathrm{a}$ are shown in Tables 9 and 10, in the analysis of upward anticipated regret in the time-limited promotions scenario, the mean value of the non-FMCG group is 3.1881, and the mean value of the FMCG group is 3.6094, $\mathrm{t}=-7.876, p=0.000(<0.05)$, indicating that in the time-limited promotions scenario, consumers will have a greater upward anticipated regret for FMCG than for non-FMCG. In the analysis of the downward anticipated regret in the time-limited promotions scenario, the mean value of the non-FMCG group is 3.6205, and the mean value of the FMCG group is 4.0236, $\mathrm{t}=-7.483, p=0.000(<0.05)$, indicating that in the time-limited promotions scenario, consumers will have stronger downward anticipated regrets for FMCG than for non-FMCG. Therefore, H4a is supported.

Table 9. The impact of different promotional product types in time-limited promotions on upward anticipated regret.

\begin{tabular}{ccccccc}
\hline Group & $\begin{array}{c}\text { Number of } \\
\text { Samples }\end{array}$ & $\begin{array}{c}\text { Standard } \\
\text { Deviation }\end{array}$ & Correlation & t & $\begin{array}{c}\text { Degree of } \\
\text { Freedom }\end{array}$ & $\begin{array}{c}\text { Significance } \\
\text { (Two-Tailed) }\end{array}$ \\
\hline Non-FMCG & 101 & 3.1881 & 0.35092 & -7.876 & 198 & 0.000 \\
FMCG & 99 & 3.6094 & 0.40417 & & 198 \\
\hline
\end{tabular}

Table 10. The impact of different promotional product types in time-limited promotions on downward anticipated regret.

\begin{tabular}{ccccccc}
\hline Group & $\begin{array}{c}\text { Number of } \\
\text { Samples }\end{array}$ & $\begin{array}{c}\text { Standard } \\
\text { Deviation }\end{array}$ & Correlation & t & $\begin{array}{c}\text { Degree of } \\
\text { Freedom }\end{array}$ & $\begin{array}{c}\text { Significance } \\
\text { (Two-Tailed) }\end{array}$ \\
\hline Non-FMCG & 101 & 3.6205 & 0.31633 & -7.483 & 198 & 0.000 \\
FMCG & 99 & 4.0236 & 0.43709 & & 198 \\
\hline
\end{tabular}

The test results of $\mathrm{H} 4 \mathrm{~b}$ are shown in Tables 11 and 12. In the analysis of the upward anticipated regret in the limited promotion scenario, the mean value of the non-FMCG group is 3.5875 , and the mean value of the FMCG group is $3.9503, \mathrm{t}=-5.143, p=0.000$ $(<0.05)$, indicating that in the restricted promotion scenario, consumers will have higher upward anticipated regrets for FMCG than for non-FMCG; in the analysis of the downward anticipated regret in the limited promotion scenario, the mean value of the non-FMCG group is 4.0099, and the mean value of the FMCG group is $4.4532, \mathrm{t}=-6.396, p=0.000$ $(<0.05)$, indicating that in the quantity-limited promotions scenario, consumers will have a stronger downward anticipated regret for FMCG than for non-FMCG. Therefore, H4b is also proved. This research conclusion is consistent with previous studies, and it also shows that FMCG is more suitable for promotion. FMCG account for a larger proportion of sales, which is more likely to stimulate anticipated regret. 
Table 11. The impact of different promotional product types in quantity-limited promotions on upward anticipated regret.

\begin{tabular}{|c|c|c|c|c|c|c|}
\hline Group & $\begin{array}{c}\text { Number of } \\
\text { Samples }\end{array}$ & $\begin{array}{l}\text { Standard } \\
\text { Deviation }\end{array}$ & Correlation & $\mathbf{t}$ & $\begin{array}{l}\text { Degree of } \\
\text { Freedom }\end{array}$ & $\begin{array}{l}\text { Significance } \\
\text { (Two-Tailed) }\end{array}$ \\
\hline Non-FMCG & 101 & 3.5875 & 0.37163 & \multirow{2}{*}{-5.143} & \multirow{2}{*}{184.857} & \multirow{2}{*}{0.000} \\
\hline FMCG & 114 & 3.9503 & 0.64146 & & & \\
\hline
\end{tabular}

Table 12. The impact of different promotional product types in quantity-limited promotions on downward anticipated regret.

\begin{tabular}{|c|c|c|c|c|c|c|}
\hline Group & $\begin{array}{c}\text { Number of } \\
\text { Samples }\end{array}$ & $\begin{array}{l}\text { Standard } \\
\text { Deviation }\end{array}$ & Correlation & $\mathbf{t}$ & $\begin{array}{l}\text { Degree of } \\
\text { Freedom }\end{array}$ & $\begin{array}{l}\text { Significance } \\
\text { (Two-Tailed) }\end{array}$ \\
\hline Non-FMCG & 101 & 4.0099 & 0.42020 & \multirow{2}{*}{-6.396} & \multirow{2}{*}{203.879} & \multirow{2}{*}{0.000} \\
\hline FMCG & 114 & 4.4532 & 0.59020 & & & \\
\hline
\end{tabular}

In the test of $\mathrm{H} 5$ and $\mathrm{H} 6$, the adjusted $\mathrm{R}^{2}$ is 0.072 , indicating that the model can explain $7.2 \%$ of the residual; $\mathrm{F}$ value is $17.156, p=0.000(<0.05)$, indicating that anticipated regret has an impact on impulsive online shopping intention. There is a significant linear relationship between anticipated regret and impulsive online buying intention, and the regression equation can be further established.

According to the analysis results in Table 13, the coefficient of the influence of the upward anticipated regret on impulsive online shopping intention is $-0.157(<0), p=0.009$ $(<0.05)$, indicating that upward anticipated regret has a significant negative impact on consumers' impulsive online shopping intention. H5 is proved. The coefficient of the influence of downward anticipated regret on impulsive online shopping intention is $0.341(>0)$, $p=0.000(<0.05)$, indicating that downward anticipated regret positively affects consumers impulsive online shopping intention. $\mathrm{H} 6$ is proved. The test results of $\mathrm{H} 5$ and $\mathrm{H} 6$ also confirmed the definitions of upward expectation regret and downward anticipated regret in previous studies. Only downward expectation regret can positively affect consumers' impulsive purchase intentions.

Table 13. Regression coefficient ${ }^{\mathrm{a}}$.

\begin{tabular}{|c|c|c|c|c|c|c|}
\hline \multirow{2}{*}{ Model } & & \multicolumn{2}{|c|}{ Unstandardized Coefficient } & \multirow{2}{*}{$\begin{array}{c}\text { Standardized Coefficient } \\
\text { Beta }\end{array}$} & \multirow[t]{2}{*}{$\mathbf{t}$} & \multirow[t]{2}{*}{ Significance } \\
\hline & & B & Standard Error & & & \\
\hline \multirow{3}{*}{1} & (Constant) & 2.840 & 0.221 & & 12.855 & 0.000 \\
\hline & Upward anticipated regret & -0.157 & 0.059 & -0.147 & -2.641 & 0.009 \\
\hline & Downward anticipated regret & 0.341 & 0.058 & 0.325 & 5.835 & 0.000 \\
\hline
\end{tabular}

a. Dependent variable: impulsive online shopping willingness.

In model checking, we first test the significance of the coefficient $\mathrm{C}$. The results show that the regression equation can be established $(\mathrm{F}=5.098, p=0.024<0.05)$. The influence coefficient of promotion type on impulsive online shopping intention is $0.126(p=0.024$ $<0.05$ ), indicating that the coefficient $\mathrm{c}$ is significant.

The second step is to test the significance of the coefficient a. With $\mathrm{F}=92.124(p=0.000$ $<0.05)$, the regression equation can be established, and the influence coefficient of the promotion type on the anticipated regret is $0.404(p=0.000<0.05)$, indicating that the coefficient is significant.

Finally, the significance of the coefficients $b$ and $c^{\prime}$ are tested, and the results are shown in Tables 14-16. With $\mathrm{F}=5.672(p=0.004<0.05)$, a regression equation can be established; the coefficient of influence of anticipated regret on impulsive online shopping intention is $0.162(p=0.013<0.05)$, indicating that the coefficient $\mathrm{b}$ is significant; the influence coefficient of promotion type on impulsive online shopping intention is 0.061 ( $p=0.322$ $>0.05$ ), indicating that the coefficient $c^{\prime}$ is not significant. The coefficients $a, b$ and $c$ are all 
significant while coefficient $\mathrm{c}^{\prime}$ is not significant meaning that the anticipated regret plays a fully mediating role. Therefore, $\mathrm{H} 7$ is proved. We once again validate the mediation role of anticipated regret.

Table 14. Model Summary ${ }^{b}$.

\begin{tabular}{ccccc}
\hline Model & $\mathbf{R}$ & $\mathbf{R}^{2}$ & Adjusted $\mathbf{R}^{2}$ & Standard Estimation Error \\
\hline 1 & $0.164^{\mathrm{a}}$ & 0.027 & 0.022 & 0.56575
\end{tabular}

a Predictor variables: (constant), anticipated regret, promotion type; ${ }^{\mathrm{b}}$ dependent variable: impulsive online shopping willingness.

Table 15. Variance Analysis ${ }^{\mathrm{a}}$.

\begin{tabular}{ccccccc}
\hline \multicolumn{2}{l}{ Model } & $\begin{array}{c}\text { Sum of } \\
\text { Square }\end{array}$ & $\begin{array}{c}\text { Degree of } \\
\text { Freedom }\end{array}$ & $\begin{array}{c}\text { Mean } \\
\text { Square }\end{array}$ & F & Significance \\
\hline \multirow{3}{*}{1} & Return & 3.631 & 2 & 1.816 & 5.672 & $0.004^{\mathrm{b}}$ \\
& Residual & 131.872 & 412 & 0.320 & & \\
\hline
\end{tabular}

a Due to variables: impulse online shopping will; ${ }^{\mathrm{b}}$ predictive variables: (constant), anticipated regret, promotion type.

Table 16. Regression Coefficients ${ }^{a}$.

\begin{tabular}{cccccccc}
\hline \multirow{2}{*}{ Model } & & \multicolumn{2}{c}{ Unstandardized Coefficient } & Standardized Coefficient & t & Significance \\
\cline { 3 - 7 } & & B & Standard Error & Beta & & \\
\hline \multirow{3}{*}{1} & (Constant) & 2.946 & 0.226 & & 13.017 & 0.000 \\
& Promotion type & 0.061 & 0.061 & 0.053 & 0.993 & 0.322 \\
& Anticipated regret & 0.162 & 0.065 & 0.134 & 2.487 & 0.013 \\
\hline
\end{tabular}

a Dependent variable: impulsive online shopping willingness.

In the test of $\mathrm{H8}$, the analysis results are shown in Table 17 , with $\mathrm{F}=59.210(p=0.000$ $<0.05)$, and the $p$ values of each interaction item of anticipated regret and impulsive traits are all less than 0.05 , indicating that the relationship between anticipated regret and impulsive traits is significant. In the influence of consumers' anticipated regret on impulsive online shopping intentions, impulsive traits have a significant moderating effect. Hypothesis H8 is proved. The establishment of this assumption also verifies the adjustment of impulsive traits in the past. That is, consumers with high impulsivity are less likely to have downward expectation regret. The final results are summarized in Table 18.

Table 17. Expected interaction of regrets and impulse traits.

\begin{tabular}{cccccc}
\hline \multirow{2}{*}{ Model } & \multicolumn{2}{c}{ Unstandardized Coefficient } & Standardized Coefficient & t & Significance \\
\cline { 2 - 6 } & B & Standard Error & Beta & 3.058 & 0.002 \\
(constant) & 2.312 & 0.756 & -0.200 & -1.179 & 0.239 \\
upward anticipated regret & -0.212 & 0.180 & 0.107 & 0.661 & -2.439 \\
$\begin{array}{c}\text { downward anticipated regret } \\
\text { impulsive traits }\end{array}$ & 0.113 & 0.170 & -1.249 & 3.409 & 0.015 \\
$\quad-1.083$ & 0.444 & 2.145 & 3.859 & 0.001 \\
$\begin{array}{c}\text { upward anticipated } \\
\text { regret-impulsive traits }\end{array}$ & 0.401 & 0.118 & 2.192 & -4.149 \\
$\begin{array}{c}\text { downward anticipated } \\
\text { regret-impulsive traits }\end{array}$ & 0.369 & 0.096 & -2.581 & 0.000 \\
$\begin{array}{c}\text { upward anticipated } \\
\text { regret-downward anticipated } \\
\text { regret-impulsive traits }\end{array}$ & -0.091 & 0.022 & & \\
\hline
\end{tabular}


Table 18. Summary of hypothesis test results.

\begin{tabular}{|c|c|}
\hline Hypothesis & Result \\
\hline $\begin{array}{l}\text { H1: Compared with the upward anticipated regret, time-limited promotions have a more significant impact on } \\
\text { the downward anticipated regret. }\end{array}$ & Support \\
\hline $\begin{array}{l}\text { H2: Compared with the upward anticipated regret, the quantity-limited promotions have a more significant } \\
\text { impact on the downward anticipated regret. }\end{array}$ & Support \\
\hline $\begin{array}{l}\text { H3: Compared with time-limited promotions, quantity-limited promotions can stimulate downward } \\
\text { anticipated regret. }\end{array}$ & Support \\
\hline $\begin{array}{c}\text { H4: Compared with non-FMCG, the online promotion of FMCG has a more significant impact on consumers' } \\
\text { anticipated regret. }\end{array}$ & Support \\
\hline $\begin{array}{l}\text { H4a: In time-limited promotions, consumers have stronger upward anticipated regret and downward } \\
\text { anticipated regret for the online promotion of FMCG. }\end{array}$ & Support \\
\hline $\begin{array}{l}\text { H4b: In limited-quality promotions, consumers have stronger upward and downward anticipated regrets for } \\
\text { online promotion of FMCG. }\end{array}$ & Support \\
\hline H5: The upward anticipated regret will negatively affect consumers' impulsive online shopping willingness. & Support \\
\hline H6: The downward anticipated regret will positively affect consumers' impulsive online shopping intentions. & Support \\
\hline $\begin{array}{l}\text { H7: In the relationship between online promotion and consumers' impulsive online shopping willingness, } \\
\text { consumers anticipated regret plays an intermediary role. }\end{array}$ & Support \\
\hline $\begin{array}{l}\text { H8: In the influence of consumers' anticipated regret on impulsive online shopping willingness, impulsive } \\
\text { traits has a significant moderating effect. }\end{array}$ & Support \\
\hline
\end{tabular}

\section{Discussion}

This paper discusses the relationship between consumer anticipated regret, promotion methods and consumer impulse purchase intention. The improved SOR model and hypotheses are put forward and regression analysis, $t$-test and other methods are employed to analyze the collected data. The following conclusions are drawn:

(1) The impact of online promotion types on consumers' anticipated regret. Online promotional activities with restrictive conditions will bring psychological pressure to consumers, prompting consumers to have different emotional responses, which express different willingness and behavior. The different restrictive conditions in online promotional activities will also affect consumers' psychological expectations. Through the independent sample $t$-test, we compare the impact of time-limited promotions and quantity-limited promotions on consumer's anticipated regret, and find that both types of promotion will have a stronger impact on consumers' downward anticipated regret than upward anticipated regret. We believe that such restrictions shorten consumers' judgment and decision-making time for promotional activities, imposing them a sense of psychological oppression, increasing their perceived risk of opportunity loss, and enhancing their downward expected regret. Compared with quantity-limited promotions, time-limited promotions stipulate the effectiveness of activities in terms of time. Consumers can enjoy discounts when buying within the specified time. Although there is no time limit for quantity-limited promotions, quantitative restrictions can induce competition among consumers thus imposing a more significant impact on downward anticipated regret.

(2) The impact of consumers' anticipated regret on impulsive online shopping willingness. Before making a purchasing decision, consumers commonly anticipate the outcome of the decision, and use counterfactual thinking to estimate their sensitivity to the anticipated regret in the two directions, and finally choose the decision that minimizes their regret. The upward anticipated regret known as regret for action is caused by upward thinking while downward anticipated regret, known as regret for inaction, is caused by downward counterfactual thinking. Through regression analysis, it is found that upward anticipated regret will inhibit impulsive online 
shopping intentions, and downward anticipated regret will promote impulsive online shopping intentions. We consider that upward anticipated regret indicates that consumers will think they can buy the products at a more favorable price, which reduces their impulsive online shopping willingness; while downward anticipated regret means that consumers consider the current price as the most favorable and thus strengthening their impulsive online shopping willingness.

(3) The mediating role of consumers' anticipated regret. Through regression analysis, this paper examines the direct impact of online promotion on impulsive online shopping intentions, and examines its indirect impact under the effect of anticipated regret. It is found that online promotion needs to affect consumers' anticipated regret before imposing an impact on impulsive online shopping intentions. We suggest that any online promotional information is just a bunch of descriptive words before the individual's cognitive processing. Only after cognitive processing can consumers have emotions and reactions to the promotional information and further change their behavior.

(4) The moderating effect of the types of promoting commodities. After grouping the questionnaire data into independent sample $t$-test analysis, the results show that in both types of limited promotion, online promotion where the promoted product is a fast-moving consumer product can have a stronger impact on consumers' anticipated regret. As the most frequently consumed commodity in life, the price of FMCG is relatively low. Retailers usually make profits by making small profits and selling more. Generally, when encountering promotional activities, consumers will be more inclined to take advantage of the opportunity which generates stronger downward anticipated regret while if promotional activities are held frequently, consumers will consider whether there will be greater discounts in the future, which will generate stronger upward anticipated regret.

(5) The moderating effect of impulsive traits. Impulsive traits are inherent characteristics of an individual, manifested as the degree of action taken without careful consideration when receiving stimuli. When facing the gain and loss of interests, impulse characteristics often affect consumers' behavior tendency. By analyzing the interaction between consumer anticipated regret and impulsive traits, it is found that impulsive traits have a significant moderating effect on the influence of consumer anticipated regret on impulsive online shopping intentions. When consumers encounter promotional activities, they will generate expected emotions based on their actual situation. This research mainly refers to the predicted regrets triggered by the increase of restrictive conditions. When consumers perceive the predicted emotions, the inherent impulsive traits will affect their willingness to take an action on this basis. The higher the impulse characteristics of consumers, the more likely they are to reduce impulse when they perceive risk or loss of benefits.

\section{Conclusions}

According to the above analysis, several suggestions for online merchants and consumers are put forward as follows:

(1) It is important for merchants to reasonably make use of the time-limited promotion and quantity-limited promotion. The results of this paper have shown that the two types of promotion have different effects on consumers' anticipated regret and both of them can affect consumers' impulsive online purchase willingness to a certain degree. The restriction is to bring psychological pressure and a sense of urgency to consumers and increase their impulsive willingness to purchase online. In addition, merchants are also suggested and should pay more attention to the promotion period and quantity. Some studies have shown that if the duration is too long in time-limited promotional activities, consumers' impulsive purchase intention will be significantly reduced, and impulsive purchase behavior will also be controlled. The same situation will happen when the quantity of promotion is too large. At the same time, it is highly 
necessary for all online merchants to measure whether the benefits of promotion activities they would like to adopt can satisfy consumers' psychological expectations and stimulate consumers' purchase willingness.

(2) Merchants should adjust their promotion strategies according to the types of promoted products to cater to consumers' different perceptions of different types of products. The life cycle of non-FMCG is longer than that of FMCG, so consumers usually need to spend more time choosing appropriate products from a large number of products in the same category, and promotional activities have a greater impact on the choice. For fast-moving consumer goods with high consumption frequency, consumers regularly buy them online. Consumers are likely to be familiar with certain brands, so they are usually able to make decisions quickly. However, the promotion activity also affects consumers' purchase willingness. Merchants need to adjust their promotion strategies based on the types of products. For example, when selling FMCG, they can appropriately increase the promotion frequency or limit the number of goods promoted to enhance consumers' downward anticipated regret, and encourage consumers to make purchase decisions quickly. As for non-FMCG, the promotion frequency should be appropriately reduced to avoid reducing consumers' perceived value.

(3) Merchants should improve promotion strategies based on the expected emotions of consumers with different impulsive characteristics. According to our results, the promotion information is considered as the main influencing factor of the expected emotion of consumers, and consumers' impulsive characteristics also affect the expected emotion. The intention of impulsive online purchase is significantly affected by both. Therefore, when developing promotion strategies, merchants should carefully consider and the expected emotions of consumers with different impulsive characteristics. As analyzed in this paper, consumers' upward anticipated regret will reduce the likelihood of purchase, and downward anticipated regret will increase the likelihood of purchase. Therefore, merchants need to manage to increase consumer's downward anticipated regret and reduce the other. For instance, slogans like "the lowest price for the whole year" and "do not miss it" could be adopted.

(4) Consumers should control their impulsive purchase willingness and avoid excessive impulsive purchases. In the era of convenient e-commence, the consumption process can be completed by moving fingers and clicking the mouse. Sometimes consumers' purchases online are driven by impulse without thinking about actual needs. Therefore, before making a purchase decision, consumers should thoroughly consider own demand, applicability for the promotional products. "Shop around" is suggested, and it is known to almost all consumers, but few can apply the theory into practice. In fact, when shopping around, the impulsive willingness to buy something will decrease, and the purchasing decisions made after comparing are more rational and more suitable for consumers' own needs. In addition, recalling some previous unsatisfactory experiences due to impulse may help consumers make a better decision when they have an impulsive willingness to purchase something.

This paper classifies anticipated regret into upward anticipated regret and downward anticipated regret. According to the analysis, the upward anticipated regret negatively affects consumers' impulsive purchase intention, while downward anticipated regret has a positive influence. In addition, this paper studies the influence of different promotion methods on upward and downward anticipated regret, elaborates the intermediary effect of consumer anticipated regret between online promotion and consumer impulsive online purchase intention, and affirms the advantages of limited promotional methods for FMCG. We put forward several suggestions for both online merchants and consumers, which will help them make better decisions for selling or purchasing online.

There are also some shortcomings in this research needed to be improved in the future. First of all, this research collected a total of 415 valid questionnaire data. The sample size is large enough statistically but not ideally. In future research, it is necessary to expand 
the sample size to improve the accuracy and applicability of our results. Secondly, the analysis of the statistical characteristics of the sample shows that the age of the respondents is concentrated between 18-25 years old. Therefore, in future research, the number of samples in each age group should be expanded according to the age structure of the online shopping group to enhance the rationality. Furthermore, in this paper, the three-day time-limited promotion and the one-hundred-piece quantity-limited promotion are set as the promotion activities. In reality, consumers cope with various promotions, and they have different expected emotions, which leads to different impulsive online purchase willingness. In future research, more types of promotion activities should be analyzed. In addition, this paper only selects snacks as the representative of FMCG and sneakers as the representative of non-FMCG. More representative products should be selected as the research object in future research. Finally, this study only studies the impact of online promotion on impulsive online purchase intention from two aspects: time-limited promotion and quantity-limited promotion. In the future, it is very important to consider the impact of more different promotion methods on consumers' impulsive online purchase intention.

Author Contributions: H.L., supervision, conceptualization, funding acquisition, methodology, validation, writing — review and editing; S.C., conceptualization, methodology, investigation, data curation, writing—original draft preparation; W.Z., investigation, resources, data curation, writingoriginal draft preparation; W.S., software, validation, investigation, S.Y., methodology, software, formal analysis, validation, visualization; X.L., project administration, resources, methodology, visualization. All authors have read and agreed to the published version of the manuscript.

Funding: This work was supported by the Discipline Co-construction Project for Philosophy and Social Science in Guangdong Province (No. GD20XGL03), the Higher Education Teaching Research and Reform Project in Guangdong Province, the Universities Stability Support Program in Shenzhen (No. 20200813151607001), the Major Planned Project for Education Science in Shenzhen (No. zdfz20017), the National Natural Science Foundation of China (No. 71901151), the Guangdong Province Soft Science Research Project (No. 2019A101002074), the Postgraduate Education Reform Project in Shenzhen University in 2019, and the Postgraduate Innovation and Development Fund Project in Shenzhen University (No. 315-0000470708).

Institutional Review Board Statement: Not applicable.

Informed Consent Statement: We conducted the research after obtaining the consent of the participants.

Data Availability Statement: Not applicable.

Conflicts of Interest: The authors declare no conflict of interest.

\section{Appendix A}

Table A1. Sample statistical characteristics.

\begin{tabular}{cccc}
\hline & Statistical Features & Number of People & Percentage \\
\hline \multirow{2}{*}{ Gender } & Male & 210 & $50.6 \%$ \\
& Female & 205 & $49.4 \%$ \\
\hline \multirow{3}{*}{ Generation } & Under 18 & 22 & $5.3 \%$ \\
& $18 \sim 25$ years old & 228 & $54.9 \%$ \\
& $26 \sim 30$ years old & 103 & $24.8 \%$ \\
& $31 \sim 40$ years old & 53 & $12.8 \%$ \\
\multirow{2}{*}{ Education } & $41 \sim 50$ years old & 9 & $2.2 \%$ \\
& College degree and below & 90 & $21.7 \%$ \\
& Undergraduate & 263 & $63.4 \%$ \\
& Master degree and above & 62 & $14.9 \%$ \\
\hline
\end{tabular}


Table A1. Cont.

\begin{tabular}{|c|c|c|c|}
\hline \multicolumn{2}{|c|}{ Statistical Features } & \multirow{2}{*}{$\begin{array}{c}\text { Number of People } \\
128\end{array}$} & \multirow{2}{*}{$\begin{array}{c}\text { Percentage } \\
30.8 \%\end{array}$} \\
\hline \multirow{8}{*}{$\begin{array}{l}\text { Average monthly } \\
\text { consumption of } \\
\text { online shopping }\end{array}$} & Below 500 & & \\
\hline & $500 \sim 1000$ & 191 & $46.0 \%$ \\
\hline & $1000 \sim 1500$ & 53 & $12.8 \%$ \\
\hline & $1500 \sim 2000$ & 23 & $5.5 \%$ \\
\hline & $2000 \sim 2500$ & 7 & 1.7 \\
\hline & $2500 \sim 3000$ & 8 & $1.9 \%$ \\
\hline & $3000 \sim 3500$ & 4 & $1.0 \%$ \\
\hline & Above 3500 & 1 & $0.2 \%$ \\
\hline \multirow{16}{*}{ Profession } & Full-time student & 185 & $44.6 \%$ \\
\hline & Production staff & 30 & $7.2 \%$ \\
\hline & Salesperson & 29 & $7.0 \%$ \\
\hline & Marketing/public relations staff & 34 & $8.2 \%$ \\
\hline & Customer service & 10 & $2.4 \%$ \\
\hline & Administrative/logistics staff & 15 & $3.6 \%$ \\
\hline & Human resources & 16 & $3.9 \%$ \\
\hline & Finance/auditor & 18 & $4.3 \%$ \\
\hline & Civilian/clerk & 17 & $4.1 \%$ \\
\hline & Technical/R\&D personnel & 15 & $3.6 \%$ \\
\hline & Manager & 14 & $3.4 \%$ \\
\hline & Teacher & 6 & $1.4 \%$ \\
\hline & Consultant/consulting & 10 & $2.4 \%$ \\
\hline & Professionals (such as & & \\
\hline & $\begin{array}{l}\text { accountants, lawyers, architects, } \\
\text { medical staff, journalists, etc.) }\end{array}$ & 11 & $2.7 \%$ \\
\hline & Other & 5 & $1.2 \%$ \\
\hline
\end{tabular}

\section{References}

1. Mo, D. Chinese Consumers Online Consumption Insight Report and Online Shopping Guide (2016). Comput. Netw. 2016, 42, 10-11.

2. Bagozzi, R.P.; Gopinath, M.; Nyer, P.U. The role of emotions in marketing. J. Acad. Mark. Sci. 1999, 27, 184-206. [CrossRef]

3. Woodworth, R. Psychology, 2nd ed.; Henry Holt: New York, NY, USA, 1929.

4. Jeong, S.W.; Fiore, A.M.; Niehm, L.S.; Lorenz, F.O. The role of experiential value in online shopping the impacts of product presentation on consumer responses towards an apparel web site. Internet Res. 2009, 19, 105-124. [CrossRef]

5. Xiao, L.; Guo, F.; Yu, F.; Liu, S. The effects of online shopping context cues on consumers' purchase intention for cross-border E-Commerce sustainability. Sustainability 2019, 11, 2777. [CrossRef]

6. Liu, C.; Zheng, Y. The predictors of consumer behavior in relation to organic food in the context of food safety incidents: Advancing hyper attention theory within an stimulus-organism-response model. Front. Psychol. 2019, 10, 2512. [CrossRef] [PubMed]

7. Akram, U.; Hui, P.; Khan, M.K.; Saduzai, S.K.; Akram, Z.; Bhati, M.H. The plight of humanity: Online impulse shopping in China. Hum. Syst. Manag. 2017, 36, 73-90. [CrossRef]

8. Liu, Y.; Li, Q.; Yin, M. The influence of internet shopping festival atmosphere on consumer impulse buying. Commer. Res. 2018, 7, $18-23$.

9. Chen, W.K.; Chen, C.W.; Lin, Y.C. Understanding the influence of impulse buying toward consumers' post-purchase dissonance and return intention: An empirical investigation of apparel websites. J. Ambient Intell. Humaniz. Comput. 2020, 12, 1-14. [CrossRef]

10. Donovan, R.; Rossiter, J. Store atmosphere: An environmental psychology approach. J. Retail. 1982, 58, $34-57$.

11. Spence, K.W. Cognitive versus stimulus-response theories of learning. Psychol. Rev. 1950, 57, 159-172. [CrossRef]

12. McCarthy, J.E.; Perreault, W.D. Basic Marketing, A Managerial Approach. U. S. McGrow Hill 2000, 40, 110.

13. Wu, Y.; Xin, L.; Li, D.; Yu, J.; Guo, J. How does scarcity promotion lead to impulse purchase in the online market? A field experiment. Inf. Manag. 2021, 58, 103283. [CrossRef]

14. Svenson, O.; Edland, A. Change of preferences under time pressure: Choices and judgements. Scand. J. Psychol. 1987, 28, 322-330. [CrossRef]

15. Payne, J.W.; Bettman, J.R.; Luce, M.F. When time is money: Decision behavior under opportunity-cost time pressure. Organ. Behav. Hum. Decis. Process. 1996, 66, 131-152. [CrossRef]

16. Webster, D.M.; Kruglanski, A.W. Cognitive and social consequences of the need for cognitive closure. Eur. Rev. Soc. Psychol. 1997, 8, 133-173. [CrossRef] 
17. Adam, M.T.P.; Krämer, J.; Müller, M.B. Auction fever! How time pressure and social competition affect bidders' arousal and bids in retail auctions. J. Retail. 2015, 91, 468-485. [CrossRef]

18. Worchel, S.; Lee, J.; Adewole, A. Effects of supply and demand on ratings of object value. J. Personal. Soc. Psychol. 1975, 32, 906. [CrossRef]

19. Teng, H.M.; Hsu, P.H.; Wee, H.M. An optimization model for products with limited production quantity. Appl. Math. Model. 2015, 39, 1867-1874. [CrossRef]

20. Cialdini, R.B.; James, L. Influence: Science and Practice; Pearson Education: Boston, MA, USA, 2009.

21. Zeelenberg, M. Anticipated regret, expected feedback and behavioral decision making. J. Behav. Decis. Mak. 1999, 12, 93-106. [CrossRef]

22. Janis, I.L.; Leon, M. Decision Making: A Psychological Analysis of Conflict, Choice, and Commitment; Free Press: New York, NY, USA, 1977.

23. Bell, D.E. Regret in decision making under uncertainty. Oper. Res. 1982, 3, 961-981. [CrossRef]

24. Loomes, G.; Sugden, R. Regret theory: An alternative theory of rational choice under uncertainty. Econ. J. 1982, 92, 805-824. [CrossRef]

25. Zeelenberg, M.; Beattie, J.; Plight, J.; Vries, N.K. Consequences of regret aversion: Effects of expected feedback on risky decision making. Organ. Behav. Hum. Decis. Process. 1996, 65, 148-158. [CrossRef]

26. Larrick, R.P.; Boles, T.L. Avoiding regret in decisions with feedback: A negotiation example. Organ. Behav. Hum. Decis. Process. 1995, 63, 87-97. [CrossRef]

27. Ritov, I.; Baron, J. Outcome knowledge, regret, and omission bias. Organ. Behav. Hum. Decis. Process. 1995, 64, 119-127. [CrossRef]

28. Lee, C.H.; Chen, C.W. Impulse Buying Behaviors in Live Streaming Commerce Based on the Stimulus-Organism-Response Framework. Information 2021, 12, 241. [CrossRef]

29. Chan, T.K.; Cheung, C.M.; Lee, Z.W. The state of online impulse-buying research: A literature analysis. Inf. Manag. 2017, 54, 204-217. [CrossRef]

30. Parboteeah, D.V.; Valacich, J.S.; Wells, J.D. The influence of website characteristics on a consumer's urge to buy impulsively. Inf. Syst. Res. 2009, 20, 60-78. [CrossRef]

31. Stern, H. The significance of impulse buying today. J. Mark. 1962, 26, 59-62. [CrossRef]

32. Youn, S.; Faber, R.J. Impulse buying: Its relation to personality traits and cues. ACR N. Am. Adv. 2000, 27, 179-185.

33. Parsad, C.; Prashar, S.; Vijay, T.S.; Kumar, M. Do promotion and prevention focus influence impulse buying: The role of mood regulation, shopping values, and impulse buying tendency. J. Retail. Consum. Serv. 2021, 61, 102554. [CrossRef]

34. Applebaum, W. Studying customer behavior in retail stores. J. Mark. 1951, 16, 172-178. [CrossRef]

35. Wang, W.Z.; Lu, H.L.; Wang, D.H. Buy or not: How the presence of others affects the occurrence of consumers' impulsive buying behavior. J. Contemp. Mark. Sci. 2020, 3, 207-224. [CrossRef]

36. Li, X.; Zheng, X.B.; Lee, M.K.O.; Zhao, D.T. Exploring consumers' impulse buying behavior on social commerce platform: The role of parasocial interaction. Int. J. Inf. Manag. 2016, 36, 333-347.

37. Lou, C.; Yuan, S.P. Influencer marketing: How message value and credibility affect consumer trust of branded content on social media. J. Interact. Advert. 2019, 19, 58-73. [CrossRef]

38. Li, J.; Guan, M.; Chen, Z. Optimal inventory policy for fast-moving consumer goods under e-commerce environment. J. Ind. Manag. Optim. 2020, 16, 1769. [CrossRef]

39. Deng, L.; Bi, W.; Liu, H.; Teo, K.L. A multi-stage method for joint pricing and inventory model with promotion constrains. Discret. Contin. Dyn. Syst.-S 2020, 13, 1653. [CrossRef]

40. Yin, C.Y.; Yu, H.Y. The Impact of Anticipated Regret on Consumer Impulse Buying Behavior. Manag. Rev. 2009, 12, 71-79.

41. Billieux, J.; Rochat, L.; Rebetez, M.M.L.; Van der Linden, M. Are all facets of impulsivity related to self-reported compulsive buying behavior? Personal. Individ. Differ. 2008, 44, 1432-1442. [CrossRef]

42. Nicolai, J.; Darancó, S.; Moshagen, M. Effects of mood state on impulsivity in pathological buying. Psychiatry Res. 2016, 244, 351-356. [CrossRef] [PubMed]

43. Nicolai, J.; Moshagen, M. Pathological buying symptoms are associated with distortions in judging elapsed time. J. Behav. Addict. 2018, 7, 752-759. [CrossRef] [PubMed]

44. Hetts, J.J.; Boninger, D.S.; Armor, D.A.; Gleicher, F.; Nathanson, A. The influence of anticipated counterfactual regret on behavior. Psychol. Mark. 2000, 17, 345-368. [CrossRef]

45. Rook, D.W.; Fisher, R.J. Normative influences on impulsive buying behavior. J. Consum. Res. 1995, 22, 305-313. [CrossRef]

46. Jones, M.A.; Reynolds, K.E.; Weun, S.; Beatty, S.E. The product-specific nature of impulse buying tendency. J. Bus. Res. 2003, 56, 505-511. [CrossRef] 